\title{
Rangeland Ecosystem Services, Risk Management, and the Ranch Bottom Line
}

\section{By Ted Toombs, Joshua H. Goldstein, Craig Hanson, Nicole Robinson-Maness, and Terry Fankhauser}

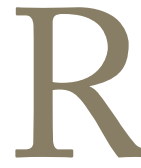

anchers manage rangelands that provide the public with valuable benefits such as clean water, wildlife habitat, recreational opportunities, and other ecosystem services. ${ }^{1}$ They are the primary stewards of large swaths of the western US landscape. Ranchers, in turn, are highly dependent on clean water, abundant vegetation, and other ecosystem services. Their businesses function primarily by harvesting rangeland vegetation and converting it into food and fiber for consumers.

Today's rancher is faced with unprecedented and complex challenges including rising production and land costs, increasing public scrutiny, and the degradation of rangelands. These challenges threaten to both increase business risk and reduce the bottom line. They also create pressure for ranchers to sell their land for housing development and other extractive purposes. Yet, the same challenges present opportunities to create mutually positive outcomes for the ranch, the public, and the land.

The future promise of payments for ecosystem services (PES) is that they could help create a new "asset class" for ranchers that could attract private and public investment and create wealth in land as an alternative to selling or using land for more extractive purposes. ${ }^{2}$ However, livestock sales currently pay the bills for most ranchers and this is likely to remain true in the near future. Although some ranchers have practiced good stewardship for decades without financial compensation, PES in the form of new markets and established government programs is making it more possible to shift emphasis toward other sources of income and to be rewarded for increased stewardship. A more diverse business strategy integrating PES also promises to reduce business risk and create new business opportunities, while providing net benefits to the public and the land. Also, simple awareness of ecosystem services can help reduce risk and change business models even without payments associated.

For this transition to become more widespread, ranchers will need a simple way to evaluate specific opportunities and risks relevant to ecosystems on their individual ranches. Without this, a clear understanding of the tradeoffs associated with different types of management may be missed, or potential business opportunities that could help ranchers expand and diversify income may be overlooked.

The Corporate Ecosystem Services Review (CESR), developed by the World Resources Institute and the World Business Council for Sustainable Development, is a decisionsupport tool designed to help corporations assess ecosystem service-related risks and opportunities and, in the process, to establish a clearer connection between ecosystem services and the company's bottom line. ${ }^{3}$ Some 300 companies have used the CESR for decision-making on matters ranging from product development to investments. In this paper, we hope to demonstrate the utility of applying the CESR to a ranching context by illustrating how the CESR's decisionmaking process can help ranchers develop business strategies that reduce risk and capitalize on opportunities presented by ecosystem services and PES.

\section{The Corporate Ecosystem Services Review Methodology}

The CESR follows a structured, five-step analytical format that guides the user through a process that culminates in the development of a comprehensive, ecosystem services-focused business strategy (Fig. 1).

In the first three steps of the CESR, the rancher 1) selects the scope of the analysis, 2) identifies priority ecosystem services for the ranch to address in its overall business strategy and operations plan by completing a tool that assesses ecosystem service dependence and impacts, and 3) completes an analysis of current trends in the priority ecosystem services with help from outside sources. At this point in the CESR, the rancher should have a clearer understanding of the ranch's dependence upon and impact on ecosystem services, and what the underlying trends are for those services. Our intent in this paper is to focus on the last two steps: 


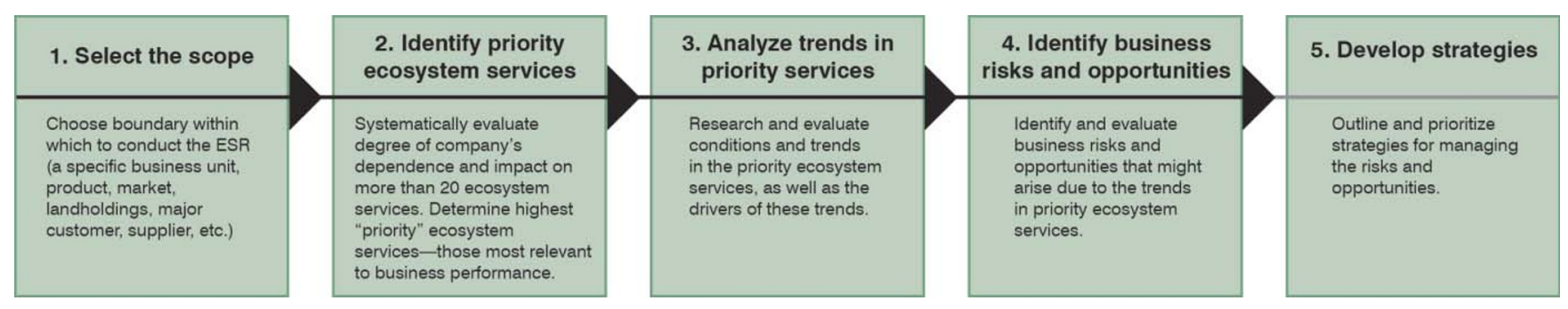

Figure 1. The five steps in the Corporate Ecosystem Services Review methodology.

4) identifying business risks and opportunities and 5) strategy development.

\section{Identifying Business Risks and Opportunities}

The CESR identifies five types of ecosystem risks and opportunities that are applicable to the ranching context (Fig. 2). Below, we define each type of risk and provide examples to motivate its relevance to a ranching operation. The outcome of this step is a comprehensive risk and opportunity analysis that addresses the priority ecosystem services identified in the prior steps and aids in the development of a new business strategy, the final step.

1. Operational risks and opportunities. Operational risks and opportunities are those related to the day-to-day expenditures and activities of the ranch. A typical expenditure in ranching is fence installation and maintenance. An example of operational risk is the increased cost of fence maintenance due to damage caused by wildlife (e.g., elk). Fence damage is an operational risk because it increases the cost of day-to-day operations. Another example of operational risk might be the time and money associated with controlling invasive weeds that threaten land and livestock productivity. It may be very difficult for a rancher to accomplish this task over thousands of acres of his or her own land, not to mention control of infestations from neighboring areas.

Through the CESR process, the rancher also identifies operational opportunities that could ameliorate the specific risks identified. Using the examples above, the rancher might discover that the state wildlife agency offers cost-share funding to install temporary fencing that could be laid down when the elk are present on the ranch thereby reducing the chance of damage and saving money. There might be an opportunity to address weed problems at the landscape scale by cooperating with the local conservation district, which may have funding to hire a weed control specialist. Not only could the opportunities reduce risk, they could also save money.

An emerging PES operational opportunity that can reduce ranch expenditures is to receive financial assistance to restore riparian and upland vegetation to improve erosion regulation, an ecosystem service that helps provide clean water for livestock and wildlife (e.g., fish). Increasingly, new PES opportunities are emerging whereby municipal water utility companies are providing this funding. One such effort, called "From Forest to Faucets," is an agreement between the Denver Water Utility and the US Forest Service to provide over 30 million dollars to restore forest health by thinning trees on private and public lands in Denver's watershed to prevent sedimentation of key reservoirs and streams in the watershed. ${ }^{4}$ This program is driven by Denver's desire to reduce long-term cost of cleaning Denver's water supply, and the US Forest Service's desire to improve forest management.

2. Regulatory risks and opportunities. Regulatory risks and opportunities are the laws, government policies, and court decisions that can affect ranch performance. The presence of endangered species is an example of regulatory risk because regulations used to protect the species might conflict with normal ranch operating procedures. For example, there might be a species that requires tall grass and willows along stream corridors for survival. In an extreme situation, the US Fish and Wildlife Service (USFWS) might require that the rancher reduce grazing pressure in riparian areas to protect the endangered species from harm.

On the other hand, the presence of the endangered species on the ranch could present a financial opportunity rather than a liability. This situation could arise if real estate developers in nearby towns were required to offset their impacts to the species' habitat through compensatory mitigation-a mechanism called "conservation banking" that applies to both wetlands and streams or species. Ranchers who create new habitat or protect existing habitat could earn "habitat credits" from the USFWS by establishing a conservation bank on their ranch or by enrolling in a regional conservation bank. The habitat credits from the bank could be marketed and sold to developers at a net profit. The market for species banking is currently estimated at 200 million dollars for species alone, and over two billion when wetlands and streams are included. ${ }^{5}$ Other opportunities might also be available in the form of regulatory assurances or financial incentives in the rancher's area, such as safe harbor agreements or farm program payments. An added benefit could result if the practices agreed to by the USFWS were also beneficial for livestock production.

3. Reputational risks and opportunities. Reputational risks and opportunities refer to the ranch's image and relationship with customers, the general public, and other stakeholders. We have often heard ranchers express concern that the general public sometimes perceives ranching as "bad for the 


\section{Operational}

The day-to-day activities, expenditures, and processes of the ranch.

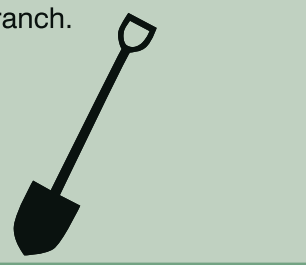

\section{Regulatory}

The laws, government policies, and court decisions that can affect ranch performance.

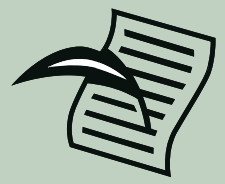

\section{Reputational}

The ranch's image and relationship with customers, the general public, and other stakeholders.

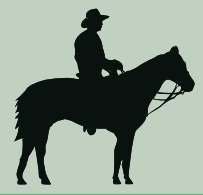

\section{Market \& Product}

The products and services provided by the ranch, public and private customer preferences, and other market factors that can affect ranch performance.

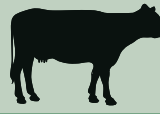

\section{Financing}

The cost and availability of capital, cash flow, and lending requirements.

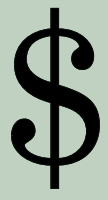

environment." In some areas of the West, especially those near urban areas, ranches have been purchased by hobby owners who view intensive livestock production as being harmful to the environment and wildlife. The presence of this type of owner might increase scrutiny on the rancher. These perceptions are of concern because they can be damaging to a rancher's reputation in the community and in extreme cases lead to land use restrictions by local regulatory authorities: a reputational risk leading to regulatory risk. The CESR can help a rancher identify opportunities to capitalize on other, more positive public perceptions that could have a beneficial effect on the ranch's overall reputation. For example, ranching culture is an iconic part of the American West that, to some, represents freedom and selfreliance, two very strong American values. Others see ranching as a sustainable land use that is compatible with the West's wide open spaces and free-ranging wildlife. Whatever these perceptions might be, the CESR can help the rancher identify them and respond to them in a constructive and strategic way.

4. Market and product risks and opportunities. Market and product risks and opportunities refer to the products and services provided by the ranch, public and private customer preferences, and other market factors that can affect ranch performance. For example, a change in government standards for grazing could make a rancher ineligible for cost-share programs if those changes are not adopted. Alternatively, the CESR might help the rancher identify a change in state regulations made in response to hunter preferences that creates new demand for access to private lands. As a result, this regulatory change could create a market and product opportunity through the rancher exploring how to acquire and market hunting permits on his or her land. Changes in public customer preferences can also create opportunities. For example, if a new federal carbon emissions "cap-and-trade" policy is adopted, the rancher could respond to this new opportunity by implementing carbon sequestration enhancing practices on their ranch, and marketing and selling their new product to carbon credit offset brokers. ${ }^{6}$ Another market and product opportunity not particularly associated with a prior risk is that increased consumer preference for "grass-fed" beef in nearby urban areas could offer the opportunity for the ranch to finish its animals on the ranch and market its beef directly to the local community.

5. Financing risks and opportunities. Financing risks and opportunities refer to the cost and availability of capital, cash flow, and lending requirements. Although environmental performance by and large does not currently limit a rancher's access to capital, it could do so in the future. Lending institutions are increasingly concerned about environmental impacts of the projects they finance, and these institutions are voluntarily

$\leftarrow$

Figure 2. Definitions of the five types of risks and opportunities identified in the Corporate Ecosystem Services Review. 
Table 1. Examples of risks and opportunities associated with priority ranch ecosystem services

\begin{tabular}{|c|c|c|c|}
\hline $\begin{array}{l}\text { Priority Ecosystem } \\
\text { Service }\end{array}$ & $\begin{array}{l}\text { Potential } \\
\text { Risks }\end{array}$ & $\begin{array}{l}\text { Potential } \\
\text { Opportunities }\end{array}$ & $\begin{array}{l}\text { Type of Risk or } \\
\text { Opportunity }\end{array}$ \\
\hline Livestock Production & $\begin{array}{l}\text { Reduced animal weight- } \\
\text { gain. } \\
\text { Scrutiny from neighbors } \\
\text { who think livestock are } \\
\text { bad for the environment. }\end{array}$ & $\begin{array}{l}\text { Cost-share payments } \\
\text { to improve grazing } \\
\text { strategy. } \\
\text { Conduct landowner } \\
\text { workshop to showcase } \\
\text { the ranch to locals and } \\
\text { the public. }\end{array}$ & $\begin{array}{l}\text { Financing } \\
\text { Operational } \\
\text { Reputational }\end{array}$ \\
\hline Primary Production & $\begin{array}{l}\text { Reduced plant production } \\
\text { due to high stocking rates, } \\
\text { invasive weeds, or other } \\
\text { factors. }\end{array}$ & $\begin{array}{l}\text { Cost-share to improve } \\
\text { forage quality. } \\
\text { Cooperation with local } \\
\text { conservation district to } \\
\text { control and manage } \\
\text { weeds. }\end{array}$ & $\begin{array}{l}\text { Operation } \\
\text { Reputatio }\end{array}$ \\
\hline $\begin{array}{l}\text { Soil Erosion } \\
\text { Regulation }\end{array}$ & $\begin{array}{l}\text { Reduced water quality for } \\
\text { livestock and wildlife due } \\
\text { to sedimentation. }\end{array}$ & $\begin{array}{l}\text { PES for watershed } \\
\text { restoration. } \\
\text { Cost-share programs } \\
\text { for restoration or } \\
\text { management. }\end{array}$ & $\begin{array}{l}\text { Operational } \\
\text { Regulatory }\end{array}$ \\
\hline Carbon Sequestration & No known risks. & $\begin{array}{l}\text { Voluntary or regulatory } \\
\text { markets for carbon } \\
\text { sequestration. }\end{array}$ & $\begin{array}{l}\text { Market } \\
\text { Operati }\end{array}$ \\
\hline Recreation & $\begin{array}{l}\text { Tresspassers cause } \\
\text { damage, conflict with } \\
\text { livestock. }\end{array}$ & $\begin{array}{l}\text { Revenue from } \\
\text { providing hunter } \\
\text { access of sale of } \\
\text { permits. }\end{array}$ & $\begin{array}{l}\text { Market \& Pro } \\
\text { Operational }\end{array}$ \\
\hline Wildlife Habitat & $\begin{array}{l}\text { Wildlife damage (e.g., elk). } \\
\text { Endangered species leads } \\
\text { to land use restrictions. } \\
\text { Poor public perception } \\
\text { of ranch as contributing } \\
\text { to the decline of wildlife } \\
\text { species or habitat. }\end{array}$ & $\begin{array}{l}\text { Species recovery cost- } \\
\text { share programs that } \\
\text { help share costs of } \\
\text { management. } \\
\text { Regulatory assurances } \\
\text { programs. } \\
\text { Establish conservation } \\
\text { banks or recovery } \\
\text { credits. }\end{array}$ & $\begin{array}{l}\text { Operational } \\
\text { Reputational } \\
\text { Market \& Product } \\
\text { Financing }\end{array}$ \\
\hline
\end{tabular}




\section{Potential Ranch Business Strategies That Address Priority Rangeland Ecosystem Services}

\section{Internal changes}

- Work collaboratively with the US Fish and Wildlife Service to create a habitat conservation bank by placing a conservation easement on part of the property and selling habitat credits to a nearby housing development; this addresses operational, regulatory, and reputational risks and opportunities.

- Enter into an agreement with the state wildlife agency to acquire annual elk hunting permits that the ranch markets to hunters. The program also offers cost-share assistance with wildlife-friendly fencing that protects hay and reduces fence damage and subsequent maintenance costs; this addresses operational and market and product risks and opportunities.

- Receive technical assistance and cost-share from a government agency to develop a grazing plan that improves water quality and reduces soil erosion; this addresses operational, regulatory, and reputational risks and opportunities.

- Establish new ranch monitoring protocols for water quality and quantity, carbon sequestration, vegetation condition, and wildlife, and receive assistance from a local nongovernmental organizations to conduct the monitoring at low cost; this addresses all types of risks and opportunities.

- Invite neighbors to hike and fish on ranch at no charge; this addresses reputational risk and opportunity.

\section{Sector or stakeholder engagement}

- Help establish a watershed-based community conservation group focused on invasive weed control; this addresses all types of risks and opportunities.

- Host community events on the ranch to showcase management changes; this addresses reputational risk and opportunity.

- Help a community group raise funds to establish watershed monitoring of water quality and quantity, vegetation, and wildlife; this addresses all risks and opportunities.

\section{Policy-maker engagement}

- Work with state cattlemen's association to promote environmental stewardship and positive social aspects of ranching in the state; this addresses reputational risk and opportunity.

- Lobby the state governor to initiate and develop new policies that help establish new regional markets for ecosystem services such as water quantity and quality, endangered species, and carbon sequestration; this addresses all types of risks and opportunities.

adopting environmentally based lending requirements. In other words, banks are actively managing the environmental and social risks of doing business, just as we are suggesting ranchers should do. For example, many large banks have adopted the "Equator Principles," 7 a set of strong, voluntary lending standards based on the International Finance Corporation's performance standards for social and environmental sustainability and designed to protect impacts to biodiversity from large-scale development projects (e.g., mining) in developing countries. Whether or not similar standards trickle down to local farm credit institutions remains to be seen, but one could imagine a future with "environmental mortgages" wherein access to affordable financial services (e.g., a lower interest rate) is provided in exchange for environmental performance. ${ }^{8}$ Indeed, this concept is currently being pilot-tested overseas. Perhaps a more plausible scenario for the near term is that the environmental performance of a ranch is perceived as a financing risk to its lending institution, for example, due to the bank's perception that the ranch could be regulated or fined over Endangered Species Act violations. If a rancher is actively managing ecosystem services sustainably, he or she stands a better chance of gaining access to capital under these potential future scenarios.

After completing the first four steps of the CESR, the rancher would have identified priority ecosystem services, analyzed trends in them and their effects on the ranch, and identified and prioritized the associated risks and opportunities (Table 1).

\section{Adopting Strategies to Reduce Risks and Maximize Opportunities}

The final step of the CESR is to develop and prioritize strategies for reducing risks and maximizing opportunities that the rancher has identified in the previous steps. Strategies can be internal, stakeholder, and/or policy oriented. Internal strategies include changes that the rancher can make on the property or within the business itself, such as changes to land management, the types of products or services offered, or marketing of those products. Stakeholder strategies involve collaboration with other entities such as nongovernmental organizations, governmental agencies, corporations, other ranchers, or the local community. Finally, policy strategies involve voicing support or opposition to policies affecting the ranch, or working with others to engage policymakers toward the same goal.

We have suggested some potential general strategies for ranches associated with key ecosystem service types. For each type of strategy and action the goal is to address the ecosystem service risk, capitalize on the opportunity, and increase the bottom line.

Of course, many of the examples provided here are not new and many ranchers are already engaged in these types 
of activities with the help of livestock associations, government agencies, nongovernmental organizations, and others. Also, it may be very difficult for ranchers to engage in all of these strategies at once, so part of the CESR process involves prioritizing the strategies themselves. These hypothetical strategies illustrate how the CESR process can assist the rancher in addressing priority ecosystem service opportunities systematically and comprehensively as part of an overall business strategy. It should also be clear how strategies involving PES can transform the business model from one focused on a single commodity (livestock sales) to one that is more diversified. In other words, diversification through PES can be a risk management strategy.

We have illustrated in a relatively straightforward way how diversification through PES can reduce risk, but how do PES impact the bottom line? The specific answer to this question is beyond the scope of this paper and would involve analysis of an individual rancher's specific situation.

However, as we expressed earlier, the sale of livestock currently pays most of the bills for the typical rancher. If the transition to PES is to become more widespread, a key financial question is whether PES can expand income sufficiently to offset transition costs and potential reductions in livestock sales due to tradeoffs with other ecosystem services. There are many long-standing examples of ranches that earn a significant portion of their income from hunting (e.g., Deseret Ranch, Utah: 30-40\% of net income), but data on the contribution of other ecosystem services to ranch income broadly are limited. ${ }^{9}$ The Farm of the Future project of USDA and Ecoagriculture Partners aims to profile farms and ranches that have made this transition and includes basic summaries of the contribution of PES to net income. ${ }^{10}$

\section{Conclusion}

Ranchers must wear many hats to ensure a successful operation, and a critical one is that of a business person. The most valuable benefit of the CESR is that it provides a simple, "low-tech" framework to help ranchers clearly analyze and capitalize on the potential opportunities associated with PES, especially if accompanied by more quantitative financial analyses. Another benefit of the CESR approach is that it can help illustrate the connection between ecosystem services and the bottom line to a much broader audience including practitioners, scientists, and policy makers who work closely with ranchers. In our experience, a clear understanding of this connection is missing from many forums on ecosystem services.

The CESR process encourages the rancher to incorporate ecosystem services as an integral part of the overall ranch business strategy, rather than as an extraneous activity or concern. Doing so can help ranchers develop businesses that are more resilient to economic and ecological change because they can proactively adapt, minimize risk, and capitalize on new opportunities as they arise. Specifically, the CESR can help ranchers better position themselves to anticipate new market opportunities, identify new sources of revenue, reduce costs, influence government policy, identify their impact and dependence upon ecosystem services, improve land management, build new stakeholder relationships, and demonstrate leadership in environmental and financial sustainability.

More generally, the CESR framework can help ranchers, and those that work with them, visualize and move toward a new, more diversified business model. For ranchers who understand the opportunities and are able to capitalize on them, PES could help fuel this transition and drive changes in management activities and priorities away from maximizing one ecosystem service (e.g., livestock production) toward optimizing management to provide a variety of ecosystem services. This shift toward "sustainable diversification" could result in rangelands that are in better overall ecological condition, better support ranchers' livelihoods, keep rural agricultural communities vibrant, and enable ranchers to be more responsive to public needs.

\section{Acknowledgments}

The authors would like to thank Ann Karpinski, Sarah Lupis, David Wolfe, David Brand, Sally Collins, and Josh Donlan for their helpful comments, suggestions, and edits.

\section{References}

1. Goldstein, J. H., C. K. Presnall, L. Lopez-Hoffman, G. P. Nabhan, R. L. Knight, G. B. Ruyle, and T. P. Tоомвs. 2011. Beef and beyond: paying for ecosystem services on western US rangelands. Rangelands 33:4-12.

2. Davis, A. 2010. Ecosystem services and the value of land. Duke Environmental Law and Policy Forum 20:339-384.

3. Hanson, C., J. Ranganathan, C. Iceland, and J. Finisdore. 2008. The corporate ecosystem services review: guidelines for identifying business risks and opportunities arising from ecosystem change. Version 1. Washington DC, USA: World Resources Institute. 48 p. Available at: www.wri.org/ecosystems/ esr. Accessed 13 June 2011.

4. Denver Water. 2011. From forests to faucets. Available at: http://www.denverwater.org/SupplyPlanning/WaterSupply/ PartnershipUSFS/. Accessed 14 June 2011.

5. Madsen, B., N. Caroll, and K. Moore Brands. 2010. State of biodiversity markets report: offset and compensation programs worldwide. Available at: http://www.thegef.org/gef/sites/thegef. org/files/publication/sbdmr.pdf. Accessed 15 June 2011.

6. Gosnell, H., N. Robinson-Mannes, and S. Charnley. 2011. Engaging ranchers in market-based approaches to climate change mitigation: opportunities, challenges, and policy implications. Rangelands 33:20-24.

7. The Equator Principles Association. 2006. The Equator Principles: a financial industry benchmark for determining, assessing and managing social and environmental risk in project financing. United Kingdom: The Equator Principals Association Miscellaneous Report. 10 p. Available at: http:// www.equator-principles.com/resources/equator_principles.pdf. Accessed 20 July 2011.

8. Mandel, J. T., C. J. Donlan, C. Wilcox, R. Cudney-Bueno, S. Pascoe, and D. Tulchin. 2009. Debt investment as a tool 
for value transfer in biodiversity conservation. Conservation Letters. 2:233-239.

9. Wolfe, M. L., G. E. Simonds, R. Danvir, and W. J. Hopkin. 1996. Integrating livestock production and wildlife in a sagebrush-grass ecosystem. US Forest Service General Technical Report No. 285. Available at: http://www.fs.fed.us/rm/pubs_ rm/rm_gtr285/rm_gtr285_073_077.pdf. Accessed 20 July 2011.

10. US Department of Agriculture. 2011. Farm of the future. Available at: http://www.usda.gov/oce/environmental_markets/ farm.htm. Accessed 20 July 2011.
Authors are Rocky Mountain Regional Director, Center for Conservation Incentives, Environmental Defense Fund, Boulder, CO 80304, USA, ttombs@edf.org (Toombs); Assistant Professor, Dept of Human Dimensions of Natural Resources, Colorado State University, Fort Collins, CO 80523, USA (Goldstein); Director, People and Ecosystems Program, World Resources Institute, Washington, DC 20002, USA (Hanson); Research Assistant, Dept of Geosciences, Oregon State University, Corvallis, OR 97331, USA (Robinson-Maness); and Executive Director, Colorado Cattlemen's Association, Arvada, CO 80002, USA (Fankhauser). 